\title{
Market Penetration and Investment Pattern: A Study of Mutual Funds in India
}

\author{
Rakesh Kumar \\ Associate Professor (Economics), Punjabi University Regional Campus, Bathinda (Punjab)
}

\begin{abstract}
This paper discusses the market penetration and investment pattern of mutual funds in India. There is very large scope for the penetration of mutual funds both geographically and investors' classes. For, the population served by such firms is meager and concentrated. The Top-15 cities contribute to $87 \%$ of the entire assets under management by mutual fund companies in the country. Besides, large share is cornered by corporates and high net worth individuals. Aggressiveness in investments did not increase over time and mutual fund companies are also risk averse instead of being risk taking firms. The Indian mutual funds companies, generally, invest in three main categories of investments namely - income, equity and liquid/money market. The efforts to popularize the other categories could not be succeeded. The accounts holding are tilted wholesomely in favour of individuals and asset holding is in favour of corporates.
\end{abstract}

Keywords: Debt and Equity, Investment Pattern, Investment Strategy, Market Penetration, Schemes,

\section{Introduction}

Firms engaged in production of goods and services are concerned about the strategic management of its marketing. For, they may be able to attract additional buyers and bigger market share. In this pursuit, they endeavor to look at the potential of their products in the existing and new markets. These strategies are technically labeled as 'market penetration' (Armstrong \& Kotler, 2009). This strategy (market penetration) increases the product sales through an aggressive marketing mix. Such approach is, usually, introduced to increase the rate of the product/service usage, encourage repeat purchases, attract consumers away from competitors and attract current non-users. In addition, such strategies include cutting prices, increasing advertising and promotional activities, and introducing innovative distributive tactics (Kotler and Keller, 2008). Marketing penetration is essential for the long term survival of firms.

The fundamental measures of a product's popularity are penetration rate and penetration share. The penetration rate is the percentage of the relevant population that has purchased a given brand or category at least once in the time period under consideration. A brand's penetration share, in contrast to penetration rate, is determined by comparing that brand's customer population to the number of customers for its category in the relevant market as a whole.

Market penetration can be materialized through existing markets and existing products (market penetration), new products and existing markets (product development), existing products and new markets (market development), new products and new markets (diversification) strategies. The targets of market penetration can be achieved through adequate information about the potential markets such as to identify the size of national markets, size of regional markets, and strategy to reach out such target groups at minimum cost. Market penetration is often very useful for the firms; as it may cause quick diffusion and adoption of product in the market along with creating goodwill among customers. Market penetration may generate efficiency for the firm; as, thinner profit margins due to aggressive pricing encourage the firm to perform better and it may discourage competitors to enter into the market. However, market penetration may always not be paying due to the fact that additional orders may be beyond the capacity of the firm.

An investment refers to the deployment of funds at present in anticipation of some positive returns in future. Funds can be invested in variety of assets, in the hope of maximizing the returns with minimum risk. Mutual funds are meant to invest in various categories of investment to maximize the returns for investors. Here, investment pattern of mutual fund firms refers to the share of different assets in total investment of the mutual fund firms. To understand the pattern of mutual fund investments have considerable bearing on the performance of the capital markets and subsequently on the entire macroeconomic environment. Therefore, it is interesting to study the investment pattern which has consequences for the individual in particular and economy in general.

The investment process is generally described in four stages namely - investment policy, investment analysis, valuation of securities and portfolio construction. Investment policy involves personal financial affairs and objectives before making investment. This stage may be considered appropriate for identifying investment assets and considering various features of investment. Further, the investors are supposed to make the analysis of available assets among the chosen class regarding their future behaviors and expected returns and associated risk. Besides, investor has to keep in mind the value of these investments. Each asset must be valued on its 
individual merit. Finally, a portfolio is constructed. A portfolio construction requires the knowledge of different aspects of assets, consisting of safety and growth of principal, liquidity of assets, selection of assets and allocations.

Investment pattern has its ramifications on the various sectors of the economy, especially when the mutual funds make their portfolio. Sometimes certain sectors are over weighted and others are under weighted. Therefore, in the developed economies, asset management companies have strength to influence the channelization of funds. In a country like India, where this industry is growing rapidly, investment pattern may affect the sectoral composition and structure of the economy to large extent. Besides, capital market may be affected by such decisions.

In wake of the foregoing discussion, present paper is devoted to study the market penetration and pattern of investment of mutual funds in India. This paper endeavors to fathom out the potential of mutual funds to penetrate into un-served areas. This will help this industry to grow in future. Besides, the reader will become aware of the fact that how the investment of mutual funds are distributed that may help the people to make their guesstimates regarding their returns, safety and liquidity.

\section{Market Penetration}

This section is devoted to study the levels of market penetration of mutual funds over time and space. This has been established in the literature of financial theory that development and financial market developments are concomitant. Since, India is less developed country and large chunk of population resides in rural areas, therefore, less penetration is obvious consequence.

Mutual fund industry sells its products in the form of mutual fund schemes to the investors. Therefore, the concept of penetration is relevant here also. Indian mutual fund industry, though, grew at tremendous rate in recent decades and the assets under management are more than 13 trillion rupees and around 45 fund houses are in operation. The population served by such firms is meager and concentrated. And it is considered that there is large scope for such firms to penetrate. The lack of participation is due to two reasons namely; (1) low demand for the mutual funds outside the major (T-15) cities. This low demand is due to the fact that low level of financial literacy, cultural attitudes towards savings and investments; (2) there is low supply of mutual funds from AMCs outside these major cities. The low supply may be due to lack demand from the general retail investors or due to lack of manpower in these areas.

Gross domestic saving is around 30 percent of the GDP in 2015 (World Bank, 2015) which is one of the highest in the world and expected to be parked in mutual funds. However, a recent report (PWC, 2013) points out that the distribution of assets under management (AUM) across cities is highly skewed in favor of the top fifteen (T-15) cities of India. The T-15 cities contribute to 87\% of the entire AUM in the country. Even within the T-15 cities, the top five cities (Mumbai, Delhi, Chennai, Kolkata and Bangalore) contribute $85 \%$ of the entire AUM at the T- 15 level i.e. 74\% of the entire AUM in the country (PWC, 2013). These results have further been vindicated by the following table-1 generated from the information provided by AMFI.

Table-1: Market Penetration (Rs Crores)

\begin{tabular}{|l|l|l|l|l|}
\hline \multirow{2}{*}{ Category of Investor } & \multicolumn{3}{|l|}{ Dec-2015 } & Mar-2014 \\
\cline { 2 - 5 } & $\mathbf{T}^{* 15}$ & $\mathbf{B}^{*}-15^{* *}$ & $\mathbf{T - 1 5}^{*}$ & B-15 $^{* *}$ \\
\hline Retail & 167256.51 & 96953.1 & 102557.19 & 60014.79 \\
Corporates & 569236.71 & 65834.41 & 403046.59 & 46073.6 \\
Banks/FI & 74197.56 & 9806.3 & 41556.12 & 4211.51 \\
FIIs/FPIs & 14316.75 & 107.42 & 7938.82 & 254.33 \\
HNIs & 309451.55 & 45863.49 & 202082.99 & 28616.19 \\
\hline Total & 1134459.08 & 218564.72 & 757217.71 & 139169.82 \\
(Percentage) & $(83.85)$ & $(16.15)$ & $(84.47)$ & $(15.53)$ \\
\hline
\end{tabular}

T-15: Top 15 Cities as identified by AMFI

B-15: Other than T15

Source: AMFI

Besides, the share of B-15 has shown decreasing trend in 2015 as compared to 2014. That is, the investable resources of mutual funds are further concentrated overtime. In addition, among the class of investors, large share is cornered by corporates and high net worth individuals. The dismal feature of penetration of Indian mutual funds is that retail investors share is very small. Hence, it can be concluded here that there is very large scope for the penetration of mutual funds both geographically and investors classes.

Out of the total net assets under management by all Mutual funds the percentage of Corporate/institutions is as big as $54.75 \%$, whereas its percentage to total investor's accounts is just $0.95 \%$. It clearly shows that the corporate sector which has a strong urban base is the real player in Mutual Funds industry. Whereas, out of the total net assets under management by all Mutual funds the percentage of 
individuals is only $39.77 \%$, where as its percentage to total investor's accounts is $97.07 \%$. This analysis clearly suggests a timely action to be taken by mutual Fund Industry regarding market penetration.

This under penetration of financial inclusion is not unique to mutual funds, but a deeper structural problem characteristic of the Indian financial sector. More than half of India's population does not have any access to formal banking services. According to 2012 World Bank Global Findex, only 35.23\% of respondents in India have an account (either self or together with someone else) at a bank or some other formal financial institution. Most Indian households tend to be extremely risk averse and cautious regarding where they invest their hard earned money. As a result, they are conservative with their savings and tend to invest in 'safe' assets. Investors perceive mutual funds as risky investments and tend to invest their savings in tangible assets such as gold, jewelry, real estate or fixed deposits in banks. These choices are a result of a mindset which has generally seen investing in stock markets and other market traded securities as akin to gambling. This is reflected by the proportion of savings of Indian households in the financial markets. The gross domestic savings and investment at current market price by households was 24.8\% of GDP 2015-16 (RBI Annual Report, 2015). The household investment in physical and financial assets was $14.3 \%$ and $8.0 \%$ respectively. The investment in shares and debentures as a percentage of gross financial savings by households was 3.6\% in 2011-12. The gross financial savings by household in mutual funds is estimated at $2.5 \%$ out of total $3.1 \%$ in shares/debentures.

The Mutual fund industry offers something for everyone. A large number of schemes are offered by AMCs and offerings are made to suit the investor's risk appetite, desired returns or period of investment. As of March 2015, more than 2000 different mutual fund schemes were on offer across AMCs (SEBI Annual Report 2014-15). Investors can choose the schemes according to the structure: Open-ended Funds or Close-ended Funds or by the objective of their investment: Growth Funds, Income Funds, Balanced Funds or Money Market Funds. Hence, there is large scope for penetration.

However, one of the ironies of having a large and established mutual fund industry is that this variation serves to intimidate rather than inform a small investor. To begin with, there exist mutual funds which focus exclusively on one type of asset class and then there are funds which hold securities from different assets. At the same time, several mutual fund schemes have two to three variants on each fund such as growth, monthly dividend, annual dividend etc. Besides offering different schemes for investment, AMCs also offer several investment plans to their customers. Systematic Investment Plans (SIPs), Systematic Withdrawal Plans (SWPs), Systematic Transfer Plans (STPs), Triggers, Insurance Options and many other plans are designed to give a degree of control and flexibility to the investor. While all this is highly beneficial for a well informed investor, all this is highly intimidating to an investor who is barely financially literate and has little time (or energy) to do his/her research before buying a fund. Boggled by all this complexity, the investor routes his savings to lesser complicated fixed deposits and/or physical assets (Halan, 2013). Lack of standardization in the processes and customer service standards create unnecessary hassles in investing (Adajania, 2013).

This combination of ignorance, risk-aversion and mutual fund complexity are huge hurdles that AMCs in India will have to overcome to improve retail participation in mutual funds. Investors need to be made to look beyond the traditional avenues of investment through sensitization and education. In addition to this, campaigns should be tailored to increase the visibility of debt funds which generally tend to be safer than equity funds.

\section{Investment by Index Funds}

\section{SEBI Guidelines For Mutual Funds Regarding Investments}

Investments by index funds shall be in accordance with the weightage of the scrips in the specific index as disclosed in the SID (Scheme Information Document). In case of sector or industry specific scheme, the upper ceiling on investments may be in accordance with the weightage of the scrips in the representative sectoral index or sub index as disclosed in the SID or 10 percent of the NAV of the scheme, whichever is higher.

\section{Investment by Liquid Fund Schemes}

The 'liquid fund schemes and plans' shall make investment in /purchase debt and money market securities with maturity of up to 91 days only. This shall also be valid in case of inter scheme transfer of securities. Any deviation from these requirements shall be viewed as violation of investment restrictions.

Investment by Close - Ended Debt Scheme

Close ended debt schemes shall invest only in such securities which mature on or before the date of the maturity of the scheme.

\section{Approval for Investment in Unrated Debt Instruments}

Mutual Funds may, for the purpose of operational flexibility, constitute committees to approve investment proposals in unrated instruments. However, detailed parameters for investment in unrated debt instruments have to be approved by the Board of the AMC and Trustees. Details of such investments shall be communicated by the AMCs to the Trustees in their periodical reports, along with clear indication as to how the 
parameters set for investments have been complied with. Prior approval of the Board of the AMC and Trustees shall be required in case investment is sought to be made in an unrated security falling outside the prescribed parameters.

\section{Investments in Units of Venture Capital Funds}

Mutual Fund schemes can invest in listed or unlisted securities or units of Venture Capital Funds within the prescribed investment limits as applicable.

\section{Investments in Short Term Deposits of Scheduled Commercial Banks}

Mutual Funds shall not park more than 15 percent of their net assets in short term deposits of all scheduled commercial banks put together. This limit, however, may be raised to 20 percent with prior approval of the Trustees. Also, parking of funds in short term deposits of associate and sponsor scheduled commercial banks together shall not exceed 20 percent of the total deployment by the Mutual Fund in short term deposits. Besides, Mutual Funds shall not park more than 10 percent of the net assets in short term deposits with any one scheduled commercial bank including its subsidiaries. And trustees shall ensure that funds of a particular scheme are not parked in short term deposit of a bank which has invested in that scheme.

\section{Participation of Mutual Funds in Repo in Corporate Debt Securities}

The gross exposure of any mutual fund scheme to repo transactions in corporate debt securities shall not be more than 10 percent of the net assets of the concerned scheme. The cumulative gross exposure through repo transactions in corporate debt securities along with equity, debt and derivatives shall not exceed 100 percent of the net assets of the concerned scheme. Mutual funds shall participate in repo transactions only in AAA rated corporate debt securities. In terms of Regulation 44 (2) of the Securities and Exchange Board of India (Mutual Funds) Regulations, 1996, mutual funds shall borrow through repo transactions only if the tenor of the transaction does not exceed a period of six months.

\section{Overseas Investment by Mutual Funds}

Aggregate ceiling for overseas investments is US \$ 7 billion and within this overall limit, Mutual Funds can make overseas investments subject to a maximum of US \$ 300 million per Mutual Fund. Aggregate ceiling for investment by Mutual Funds in overseas Exchange Traded Fund ETFs that invest in securities is US \$1 billion subject to a maximum of US \$ 50 million per Mutual Fund. Overseas investments which are permissible include ADRs, GDRs issued by Indian and foreign companies, equity of overseas companies listed on recognized stock exchanges overseas, initial and follow on public offerings for listing at recognized stock exchanges overseas, foreign debt securities with fully convertible currencies, short term as well as long term debt instruments, money market instruments with rating not below investment grade by rating agencies and government securities where the countries are rated not below investment grade.

Overseas investments by mutual funds also include derivatives traded on recognized stock exchanges overseas only for hedging and portfolio balancing with underlying as securities.

\section{Norms for Investment by Mutual Funds in Derivatives}

The cumulative gross exposure through equity, debt and derivative positions should not exceed 100 percent of the net assets of the scheme. Mutual Funds shall not write options or purchase instruments with embedded written options. The total exposure related to option premium paid must not exceed 20 percent of the net assets of the scheme. Exposure due to derivative positions taken for hedging purposes in excess of the underlying position against which the hedging position has been taken, shall be treated under the limits. Exposure is the maximum possible loss that may occur on a position.

\section{Investment Pattern}

Asset management companies are supposed to invest the funds mobilized from the investors in various schemes designed according to the requirements of the investors. The fund manager manages the funds in such a way that he is able to generate maximum returns. Besides, investment pattern also comprises the nature of investors who contributes to the assets under management of asset management companies. Such knowledge helps to understand the general trends of investments; consequently, suitable policies can be framed to direct them towards particular direction.

\section{Instruments of Investment}

There are various financial instruments for mutual fund organizations to investment and reap returns, in turn distribute the same in the form of dividend or interest to their unit holders (investor). Such instruments are as under; 
- Equity shares

- Convertible debentures

- $\quad$ Fixed Income Securities include - debt instruments (non-convertible debentures), bonds of public sector and government securities (Gilts)

- Money Market Instruments include - certificates of deposits, treasury bills, commercial paper, bill discounting, call money

The following table-2 highlights the investment pattern of mutual funds according to aforementioned instruments.

Table-2: Investment Pattern of Mutual Funds-Security Wise (in Rs Crores)
\begin{tabular}{|l|l|l|}
\hline Instrument & $\mathbf{2 0 0 8 - 0 9}$ & Dec 2015 \\
\hline Equity Shares & $196893.49(33.72)$ & $427077.11(32.65)$ \\
Debentures/Bonds & $101598.19(17.40)$ & $324270.46(24.79)$ \\
Govt. Securities & $52692.96(11.65)$ & $128871.05(9.9)$ \\
Bank FDs & $19234.11(3.29)$ & $25436.28(1.9)$ \\
Certificates of Deposits & $141122.77(24)$ & $140750.70(10.77)$ \\
CDs/CPs & $22.132 .89(3.79)$ & $195592.03(14.96)$ \\
Others & $50123.98(8.6)$ & $65751.75(5)$ \\
\hline
\end{tabular}

Source: AMFI, Note: Figures in parentheses are percentages

The table reveals that there is considerable jump in investments in debentures/bonds category from 17.40 percent in 2008-09 to 24.79 percent in December 2015. Besides, remarkable increase has also been witnessed in CDs/CPs category from 3.79 percent in 2008-09 to about 15 percent in December 2015. However, a decline has been recorded in bank FDs. It can be concluded here that mutual fund companies' investments are trending towards debt instruments along with away from bank fixed deposits. Contrary to the established belief that equity investments increase overtime could not be proved in India as investments in equity instruments are more or less same during last 8 years. Therefore, we can say that aggressiveness in investments did not increase over time and mutual fund companies are also risk averse instead of being risk taking firms. This may be due the nature of demand for such instruments by investors.

\section{Classification of Investments by AMFI}

AMFI classifies the funds into the following eight categories:

1. Liquid/Money Market Funds

2. Gilt Funds

3. Debt Oriented Funds

4. Equity Oriented Funds

5. Balanced Funds

6. Gold Exchange Traded Funds

7. Exchange Traded Funds (Other than Gold)

8. Fund of Funds (Investing Overseas)

The ensuing discussion is devoted to investment pattern of mutual funds according to the AMFI classification of funds. In this context, table-3 through light on insights regarding such pattern overtime.

Table-3: Category-Wise Assets under Management

\begin{tabular}{|c|c|c|c|c|c|c|}
\hline \multirow[b]{2}{*}{ Fund Category } & \multicolumn{2}{|l|}{ Dec 2004} & \multicolumn{2}{|l|}{ Dec 2008} & \multicolumn{2}{|l|}{ Dec 2015} \\
\hline & $\begin{array}{l}\text { No. of } \\
\text { Schemes }\end{array}$ & $\begin{array}{l}\text { Amount } \\
\text { (Rs. Crore) }\end{array}$ & $\begin{array}{l}\text { No. of } \\
\text { Schemes }\end{array}$ & $\begin{array}{l}\text { Amount } \\
\text { (Rs. Crore) }\end{array}$ & $\begin{array}{l}\text { No. of } \\
\text { Schemes }\end{array}$ & $\begin{array}{l}\text { Amount } \\
\text { (Rs. Crore) }\end{array}$ \\
\hline Income & 136 & $47451(32)$ & 539 & $197132(48)$ & 1517 & $555364(44)$ \\
\hline Balanced & 37 & $5472(04)$ & 35 & $11348(03)$ & 27 & $42193(04)$ \\
\hline Liquid/ Money Market & 38 & $59447(39)$ & 57 & $82776(20)$ & 54 & $232970(18)$ \\
\hline Gilt & 30 & $4876(03)$ & 32 & $6368(02)$ & 41 & $17463(01)$ \\
\hline Other ETF & - & - & 11 & $1761(0.004)$ & 44 & $11887(01)$ \\
\hline Fund of Funds (Overseas) & - & - & 10 & $2588(0.006)$ & 31 & $2023(0.002)$ \\
\hline Total & 419 & $150537(100)$ & 1023 & $413365(100)$ & 2201 & $1274835(100)$ \\
\hline
\end{tabular}

Source: AMFI, Note: Figures in Parentheses are percentages

So far the number of schemes offered to the investors is concerned; these have recorded considerable growth overtime. For instance 2201 schemes were available to investors in December 2015 compared to 1023 in 
December 2008 and 419 in December 2004. This information indicates that scope of mutual fund industry in India has expanded overtime and better space has been provided to investors. So far the distribution of such schemes in various categories is concerned large chunk of increase in schemes is cornered by income category funds and followed by equity oriented funds. More than 80 percent of schemes fall in these two categories (income and equity). However, other categories did not witness much change except ETFs and FoFs. ETFs were nonexistent in December 2004, and now there are 13 schemes related to Gold ETFs and 44 other ETFs. Fund of funds is one more category which emerged on the scene in recent years.

So far category wise assets under management are concerned, major share (more than 70 percent) is dominated by income and equity categories. The share of income funds which was 32 percent in December 2004, has increased to 48 percent in 2008; however, declined to 44 percent in December 2015. The equity segment increased to 29 percent in December from 21 percent in December 2004. The liquid/money market category has lost its sheen overtime from 39 percent in December 2004 to 18 percent in December 2015. Therefore, it can be concluded here that Indian mutual fund companies invest in three main categories namely income, equity and liquid/money market. The table also reveals that efforts to popularize the other categories could not be succeeded. The earlier result of risk avoiding society has further been corroborated.

The Indian mutual fund industry is almost Rs. 13 trillion strong with fixed income or debt having a two third share about Rs 9 trillion, the rest being largely equity. The share of debt funds has not changed much from a decade ago when the industry size was less than Rs 2 lakh crore.

\section{Unit Holding Pattern}

Mutual funds unit holders are generally classified into four major categories namely-individuals, NRIs, FIIs and Corporates/Institutions. Such classification helps to understand the distribution of mutual fund services and benefits of mutual fund schemes to the different segments of the society. In this regard, table- 4 is presented below;

Table-4: Unit Holding Pattern of Mutual Fund Industry

\begin{tabular}{|c|c|c|c|c|c|c|c|c|c|c|c|c|}
\hline \multirow[b]{2}{*}{ Category } & \multicolumn{4}{|c|}{ March 31,2002 } & \multicolumn{4}{|c|}{ March 31, 2009} & \multicolumn{4}{|c|}{ March 31,2010 } \\
\hline & $\begin{array}{l}\text { Number of } \\
\text { Investors } \\
\text { Account }\end{array}$ & $\begin{array}{l}\text { \%age of } \\
\text { total } \\
\text { Investors } \\
\text { Accounts }\end{array}$ & $\begin{array}{l}\text { Net } \\
\text { Assets } \\
\text { (Rs. } \\
\text { Crore) }\end{array}$ & $\begin{array}{l}\text { \%age } \\
\text { of total } \\
\text { net } \\
\text { assets }\end{array}$ & $\begin{array}{l}\text { Number } \\
\text { of } \\
\text { Investors } \\
\text { Account }\end{array}$ & $\begin{array}{l}\text { \%age of } \\
\text { total } \\
\text { Investors } \\
\text { Accounts }\end{array}$ & $\begin{array}{l}\text { Net Assets } \\
\text { (Rs. Crore) }\end{array}$ & $\begin{array}{l}\text { \%age of } \\
\text { total net } \\
\text { assets }\end{array}$ & $\begin{array}{l}\text { Number } \\
\text { of } \\
\text { Investors } \\
\text { Account }\end{array}$ & $\begin{array}{l}\text { \%age of } \\
\text { total } \\
\text { Investors } \\
\text { Accounts }\end{array}$ & $\begin{array}{l}\text { Net } \\
\text { Assets } \\
\text { (Rs. } \\
\text { Crofe) }\end{array}$ & $\begin{array}{l}\text { \%age of } \\
\text { total net } \\
\text { assets }\end{array}$ \\
\hline $\begin{array}{l}\text { Individuals } \\
\text { NRIs } \\
\text { FIls } \\
\text { Corporates/ } \\
\text { Institutions }\end{array}$ & $\begin{array}{l}30238065 \\
154622 \\
1123 \\
450132\end{array}$ & $\begin{array}{l}98.04 \\
0.50 \\
0.00 \\
1.46\end{array}$ & $\begin{array}{l}55487 \\
1398 \\
306 \\
43403\end{array}$ & $\begin{array}{l}55.16 \\
1.39 \\
0.30 \\
43.15\end{array}$ & $\begin{array}{l}46075763 \\
971430 \\
146 \\
575938\end{array}$ & $\begin{array}{l}96.75 \\
2.04 \\
0.00 \\
1.21\end{array}$ & $\begin{array}{l}155283.21 \\
22821.28 \\
4983.82 \\
236233.35\end{array}$ & $\begin{array}{l}37.03 \\
5.44 \\
1.19 \\
56.34\end{array}$ & $\begin{array}{l}46327683 \\
943482 \\
216 \\
452330\end{array}$ & $\begin{array}{l}97.07 \\
1.98 \\
0.00 \\
0.95\end{array}$ & $\begin{array}{l}245390 \\
27429 \\
6335 \\
337813\end{array}$ & $\begin{array}{l}39.77 \\
4.45 \\
1.03 \\
54.75\end{array}$ \\
\hline Total & 30843942 & 100 & 100594 & 100 & 47623277 & 100 & 419321.66 & 100 & 47723711 & 100 & 616967 & 100 \\
\hline
\end{tabular}

Source: AMFI

The investors hold account with the mutual fund companies, as they invest in the schemes offered by them. The account holding pattern has been skewed in favour of individuals, as 97 percent of the accounts are held by them. This ratio remained, more or less, same overtime. Two percent accounts are held by NRIs and one percent belongs to corporates/institutions. However, the contribution of FIIs is negligible.

However, net assets held by categories show very different picture. The corporates holding accounts ranging from one to one and half percent are holding more than 50 percent of the share in net assets. Whereas, individuals holding 97 percent of accounts are holding 40 percent share of net assets. Around 5 percent share is held by NRIs with 2 percent shares in accounts. Hence, it can be concluded from the foregoing discussion that accounts holding is tilted wholesomely in favour of individuals and asset holding is in favour of corporates. Such result is a matter of concern and suggest for more net assets in favour of individuals for percolating benefits of mutual funds.

\section{Liquid/Money Market Schemes}

Mutual fund companies have investments of 18 percent of their total investment in this category. The categories of investors interested in the liquid/money market schemes are presented in table-5. 
Table-5: Liquid/Money Market Schemes

\begin{tabular}{|l|l|l|l|l|l|l|l|l|l|}
\hline \multirow{2}{*}{ Investor } & $\mathbf{2 0 0 9}$ & $\begin{array}{l}\text { AUM (Rs. } \\
\text { Crores) }\end{array}$ & $\begin{array}{l}\text { \%age of } \\
\text { total }\end{array}$ & $\begin{array}{l}\text { No. of } \\
\text { Folios }\end{array}$ & $\begin{array}{l}\text { \% of } \\
\text { total }\end{array}$ & $\begin{array}{l}\text { AUM (Rs. } \\
\text { Crores) }\end{array}$ & $\begin{array}{l}\text { \%age } \\
\text { total }\end{array}$ & $\begin{array}{l}\text { No. } \\
\text { Folios }\end{array}$ & $\begin{array}{l}\text { \% } \\
\text { total }\end{array}$ \\
\hline Corporates & 66324.70 & 73.65 & 14540 & 8.47 & 201036.57 & 86.29 & 28234 & 8.04 \\
Banks/FIs & 14541.66 & 16.15 & 204 & 0.12 & 9319.93 & 4.00 & 763 & 0.22 \\
FIIs & 1438.03 & 1.60 & 35 & 0.02 & 432.26 & 0.19 & 37 & 0.01 \\
HNIs & 7081.80 & 7.86 & 23758 & 13.85 & 18294.62 & 7.85 & 59369 \\
Retail & 672.85 & 0.75 & 133028 & 77.53 & 3886.67 & 1.67 & 262690 \\
Total & 90059.04 & 100 & 171565 & 100 & 232970.05 & 100 & 74.91 \\
\end{tabular}

Source: AMFI

The table depicts that 86 percent of assets are held by corporates followed by high net worth individuals with 8 percent share in total assets. The corporates' share has improved overtimes whereas it remained same in HNIs category. However, Banks/FIs share had come down to 4 percent in 2015 compared to 16 percent in 2009. Besides, though individuals are holding majority of folios their share in liquid/money market assets is miniscule (less than 2 percent). What is the implication of such distribution in liquid/money market schemes? Banks/FIs do not have short term surplus funds to park in liquid/money market funds. However, corporates have short term surplus funds and they put such funds in liquid/money market funds. Above all retail investors are not much interested in this variety of funds.

\section{Debt Oriented Schemes}

Variety and convenience are two factors that stand out in favour of debt oriented mutual funds. In terms of variety, debt funds are available across horizons and risk appetites. Accordingly, they can be broadly classified into short term and long term debt funds. For short term investment horizons one may choose between liquid funds (3-6 months), ultra short term debt funds (less than one year) and short term debt funds (less than 3 years). One may choose income and gilt funds if investment horizon is more than 3 years.

Such schemes are, generally, considered as risk free; however, they have tax implications for the investors. Therefore, different categories have different reactions to such schemes. Investors' distribution in debt oriented funds is presented in table-6.

Table-6: Debt Oriented Funds

\begin{tabular}{|c|c|c|c|c|c|c|c|c|}
\hline \multirow{2}{*}{ Investor } & \multicolumn{4}{|l|}{2009} & \multicolumn{4}{|l|}{2015} \\
\hline & $\begin{array}{l}\text { AUM (Rs. } \\
\text { Crores) }\end{array}$ & $\begin{array}{l}\text { \%age of } \\
\text { total }\end{array}$ & $\begin{array}{l}\text { No. } \\
\text { Folios }\end{array}$ & $\begin{array}{l}\% \text { of } \\
\text { total }\end{array}$ & $\begin{array}{l}\text { AUM (Rs. } \\
\text { Crores) }\end{array}$ & $\begin{array}{l}\text { \%age of } \\
\text { total }\end{array}$ & $\begin{array}{ll}\text { No. } & \text { of } \\
\text { Folios } & \\
\end{array}$ & $\begin{array}{ll}\% & \text { of } \\
\text { total }\end{array}$ \\
\hline Corporates & 127845.36 & 64.75 & 73072 & 2.60 & 318212.3 & 57.14 & 112557 & 1.49 \\
\hline Banks/FIs & 2668.60 & 1.35 & 5135 & 0.18 & 9777.14 & 1.76 & 1498 & 0.02 \\
\hline FIIs & 2456.94 & 1.24 & 24 & 0 & 8374.04 & 1.5 & 63 & 0.00 \\
\hline HNIs & 56411.14 & 28.57 & 177596 & 6.32 & 174886.34 & 31.41 & 665640 & 8.84 \\
\hline Retail & 8070.63 & 4.09 & 255270 & 90.90 & 45613.7 & 8.19 & 6752804 & 89.65 \\
\hline Total & 197452.68 & 100 & 2811097 & 100 & 556863.52 & 100 & 7532562 & 100 \\
\hline
\end{tabular}

Source: AMFI

Investments in debt oriented schemes are dominated by corporates with 65 percent share in 2009; however, it declined to 57 percent in 2015. The high net worth individuals also has considerable interest in debt oriented instruments of mutual funds. They hold 31 percent of assets under management in these schemes and increased overtimes from 29 percent in 2009. Retail investors have shown considerable interest in such schemes. The share of retail investors was 4 percent in 2009 which increased to 8 percent in 2015. Banks/FIs do not have much interest in such instruments, given the nature of such institutions. As expected, majority of folios are held by individuals. Major conclusion from this table is that about 90 percents of investments in debt oriented schemes are cornered by corporates and HNIs.

\section{Equity Oriented Schemes}

"Mutual funds are subject to market risks" is most relevant for equity oriented schemes. Investors who have risk appetite are, generally, interested in this category of schemes. Obviously, the different results are expected in investment patterns of equity oriented schemes. Results are presented in table-7. 
Table-7: Equity Oriented Funds

\begin{tabular}{|l|l|l|l|l|l|l|l|l|l|}
\hline \multirow{2}{*}{ Investor } & $\mathbf{2 0 0 9}$ & $\begin{array}{l}\text { AUM (Rs. } \\
\text { Crores) }\end{array}$ & $\begin{array}{l}\text { \%age of } \\
\text { total }\end{array}$ & $\begin{array}{l}\text { No. of } \\
\text { Folios }\end{array}$ & $\begin{array}{l}\text { \% of } \\
\text { total }\end{array}$ & $\begin{array}{l}\text { AUM (Rs. } \\
\text { Crores) }\end{array}$ & $\begin{array}{l}\text { \%age } \\
\text { of total }\end{array}$ & $\begin{array}{l}\text { No. } \\
\text { Folios }\end{array}$ & $\begin{array}{l}\text { \% } \\
\text { total }\end{array}$ \\
\hline Corporates & 13213.20 & 12.07 & 440280 & 1.06 & 61656.36 & 15.2 & 256683 & 0.74 \\
Banks/FIs & 1863.21 & 1.70 & 2727 & 0.01 & 1550.74 & 0.38 & 833 & 0.0 \\
FIIs & 834.41 & 0.76 & 74 & 0.00 & 4164.14 & 1.03 & 98 & 0.0 \\
HNIs & 22589.06 & 20.63 & 355243 & 0.85 & 130338.41 & 32.13 & 856137 & 2.47 \\
Retail & 71012.71 & 64.84 & 40906104 & 98.09 & 207952.64 & 51.26 & 33599662 & 96.79 \\
Total & 109512.59 & 100 & 41704428 & 100 & 405662.28 & 100 & 34713413 & 100 \\
\hline
\end{tabular}

Source: AMFI

Interestingly, individuals and high net worth individuals are more interested in taking risk compared to other categories of investors. Table-7 reveals that more than 80 percent of funds are held by individuals and HNIs. This share has increased from 75 percent in 2009. Along with, corporates have considerable interest in equity oriented schemes. And they have improved their share overtime from 12 percent in 2009 to 15 percent in 2015. This has been established in the literature of investments that more risks are related to more returns. The major inference from the foregoing discussion is that HNIs are supposed to be risk takers and individuals are also trending towards such appetite.

\section{Balanced Funds Schemes}

Since balanced fund schemes are designed in such way that some returns are assured through combination of debt and equity instruments. The distribution of investments in balanced funds among investors is presented in table- 8 .

Table-8: Balanced Funds

\begin{tabular}{|l|l|l|l|l|l|l|l|l|l|}
\hline \multirow{2}{*}{ Investor } & $\mathbf{2 0 0 9}$ & $\begin{array}{l}\text { AUM (Rs. } \\
\text { Crores) }\end{array}$ & $\begin{array}{l}\text { \%age of } \\
\text { total }\end{array}$ & $\begin{array}{l}\text { No. of } \\
\text { Folios }\end{array}$ & $\begin{array}{l}\text { \% of } \\
\text { total }\end{array}$ & $\begin{array}{l}\text { AUM (Rs. } \\
\text { Crores) }\end{array}$ & $\begin{array}{l}\text { \%age of } \\
\text { total }\end{array}$ & $\begin{array}{l}\text { No. } \\
\text { Folios }\end{array}$ & $\begin{array}{l}\text { \% } \\
\text { of } \\
\text { total }\end{array}$ \\
\hline Corporates & 1059.42 & 9.09 & 12776 & 0.53 & 7476.69 & 17.72 & 25003 & 1.07 \\
Banks/FIs & 52.77 & 0.45 & 112 & 0.00 & 43.88 & 0.1 & 67 & 0 \\
FIIs & 1.07 & 0.01 & 2 & 0.00 & 35.65 & 0.08 & 3 & 0 \\
HNIs & 2589.74 & 22.23 & 32003 & 1.32 & 20310.57 & 48.14 & 112607 & 4.8 \\
Retail & 7946.83 & 68.21 & 2373594 & 94.14 & 14325.89 & 33.95 & 2207712 & 94.13 \\
Total & 11649.82 & 100 & 2418487 & 100 & 42192.67 & 100 & 2345392 & 100 \\
\hline
\end{tabular}

Source: AMFI

Most interested in balanced fund schemes were retailers accounting for 68.21 percent in 2009. However, this share has declined to 34 percent in 2015. We can say that the retail investors' interest has declined in balanced fund schemes overtime. However, most interested in such schemes are HNIs who cornered 48 percent share of AUM increased from 22 percent in 2009. Besides, corporates have also improved from 9 percent in 2009 to 18 percent in 2015.

Other categories of fund schemes, so far AUM of these schemes are concerned, are insignificant and do not deserved to be discussed here in detail. On the basis of risk, one needs to look at interest rate risk and credit risk. The former is due to change in rates in the economy. This risk can be gauged by average tenure of portfolio holdings - longer the tenure, higher the interest rate risk. Accordingly, liquid funds carry the least interest rate risk while gilt funds carry the highest interest rate risk. In terms of credit risk (risk of default or delay in payment of interest and principal), gilt funds carry nil credit risk as they hold sovereign bonds.

But we still have a long way to go as RBI data indicates that about Rs 90 trillion is parked in bank deposits, 10 times the money in debt mutual funds and over 35 times the retail debt AUM. This is mainly due to lack of awareness about the benefits offered by debt funds besides the 'assured returns' psyche of retail investors. This is bound to change as overall interest rates are likely to fall as India grows.

\section{Concluding Remarks}

This paper discusses the market penetration and investment pattern of asset management companies (AMCs) in India. Investment pattern has its ramifications on the various sectors of the economy. In a country like India, where this industry is growing rapidly, investment pattern may affect the sectoral composition and structure of the economy to large extent. Indian mutual fund industry grew at tremendous rate in recent decade and the assets under management are more than 13 trillion rupees and about 45 fund houses are in operation. The population served by such firms is meager and concentrated. The T-15 cities contribute to $87 \%$ of the entire AUM in the country. Even within the T-15 cities, the top five cities (Mumbai, Delhi, Chennai, Kolkata and Bangalore) contribute $85 \%$ of the entire AUM at the T- 15 level i.e. $74 \%$ of the entire AUM in the country. Besides, large share is cornered by corporates and high net worth individuals. Hence, there is very large scope 
for the penetration of mutual funds both geographically and investors' classes. This combination of ignorance, risk-aversion and mutual fund complexity are huge hurdles that AMCs in India will have to overcome if there is to be any increase in retail participation in mutual funds. Investors need to be made to look beyond the traditional avenues of investment through sensitization and education.

Contrary to the established belief that equity investments increase overtime could not be proved in India. Aggressiveness in investments did not increase over time and mutual fund companies are also risk averse instead of being risk taking firms.

This has been established that the scope of mutual fund industry in India has expanded overtime and better space has been provided to investors. So far the distribution of such schemes in various categories is concerned large chunk of increase in schemes is cornered by income category funds and followed by equity oriented funds. More than 80 percent of schemes fall in these two categories (income and equity). Indian mutual fund companies invest in three main categories namely - income, equity and liquid/money market. The efforts to popularize the other categories could not be succeeded.

The accounts holding are tilted wholesomely in favour of individuals and asset holding is in favour of corporates. Banks/FIs do not have short term surplus funds to park in liquid/money market funds. However, corporates have short term surplus funds and they put such funds in liquid/money market funds. Above all, retail investors are not much interested in this variety of funds. Investments in debt oriented schemes are dominated by corporates. The high net worth individuals also has considerable interest in debt oriented instruments of mutual funds. And about 90 percents of investments in debt oriented schemes are cornered by corporates and HNIs. HNIs are supposed to be risk takers and proved true for India and individuals are also trending towards such appetite.

But we still have a long way to go as RBI data indicates that about Rs 90 trillion is parked in bank deposits, 10 times the money in debt mutual funds and over 35 times the retail debt AUM. This is mainly due to lack of awareness about the benefits offered by debt funds besides the 'assured returns' psyche of retail investors. This is bound to change as overall interest rates are likely to fall as India grows.

\section{References}

[1]. Adajania K. E. (2013), "MF Industry Needs to Look at Standardization in a New Light”, HT Mint, September 04.

[2]. Armstrong G. \& Kotler P. (2009), "Marketing. An Introduction", 9th ed. Prentice Hall.

[3]. Halan M. (2013), "Why do Indians Buy so much Gold Jewelry?" HT Mint, June 11.

[4]. Kotler P. (2000), "Marketing Management Analysis, Planning Implementation and Control", Englowood Cliffs, New Jersey Prentice Hall, Inc.

[5]. Kotler P., Keller K. L. (2008), "Marketing Management", 12th ed., Prentice-Hall.

[6]. Markowitz H.M. (1952), "Portfolio Selection", The Journal of Finance, 7 (1), 77-91.

[7]. PWC (2013), "Indian Mutual Fund Industry: Unearthing the Growth Potential in Untapped Markets", CII, available at: www.pwc.com

[8]. World Bank Report (2015)

[9]. www.amfiindia.com

[10]. www.sebi.gov.in 